A year in the public life of superbugs: News media on antimicrobial resistance and implications for health communications

Mark Davisa,*, Benjamin Lyall ${ }^{a}$, Andrea Whittaker ${ }^{a}$, Mia Lindgren ${ }^{b}$, Monika Djerf-Pierre ${ }^{c}$, Paul Flowers $^{\mathrm{d}}$

aSchool of Social Sciences, Monash University, Australia

bFaculty of Arts, Social Sciences and Humanities, Swinburne University of Technology,

Australia

cDepartment of Journalism, Media and Communication, University of Gothenburg, Sweden dSchool of Psychological Sciences and Health, University of Strathclyde, United Kingdom 


\title{
A year in the public life of superbugs: News media on antimicrobial resistance and implications for health communications
}

\author{
Abstract \\ News media can be an important source of information about emerging health threats. They are \\ also significant sites for the production of narrative on threats to life that help to condition and \\ reflect the responses of governments and publics. Antimicrobial resistance (AMR) is one such \\ health threat with particular significance because it represents the failure to manage the risks to \\ antibiotics and other antimicrobials, health technologies that have provided the basis for modern \\ medicine. Knowledge of how news media address this situation is an important element for an \\ effective public health response to AMR and helps to extend the social analysis of health and \\ media. Based on an analysis of television, printed and digital news for 2017 in Australia, this \\ paper examines the patterns and meanings of AMR news. It shows that AMR is a fragmented \\ story mainly framed by scientific discovery. These stories reassure audiences that science is \\ seeking out the means of arresting AMR and, therefore, also constructs lay publics as passive \\ witnesses to the AMR story. This pattern of AMR story-telling furthers the social standing of \\ science and scientists, but it also neglects deliberation on collective action, important lacunae in \\ the social response to AMR.
}

\section{Keywords}

Australia

Antimicrobial resistance

Superbugs

Media 
This paper investigates the role news media can play in the global effort to reduce the impact of antimicrobial resistance (AMR). It can be shown that news media and AMR have been entwined since the widespread use of penicillin in the 1940s. Howard Florey, who pioneered the clinical application and manufacture of penicillin, cautioned of 'penicillin-resistance' in an Australian newspaper in 1944 (Staff Correspondent, 1944). This news report came soon after other reports of the miraculous curative powers of penicillin. For example, the immunologist Frank Macfarlane Burnet wrote about the discovery of antibiotics in The Age (1941). News media have also popularised the term 'superbugs'. In Australia, the earliest use of the term we identified dates to a 1947 item on the inception of the state of Victoria's blood bank (Brennan, 1947). In this case the safety of blood donation was justified because only a 'superbug' could possibly overcome the bank's hygiene measures. These examples indicate that AMR narratives have in part been brought into existence through news media, an important insight for policy and social analysis of public life and emerging threats to health.

It is commonly argued, too, that news media can provide individuals with access to information about new health threats and the means to overcome them (Washer and Joffe, 2006), including for AMR (Bie et al., 2016). This property of news media was evident in the 1980s emergence of the then new infection HIV, which was marked by extensive reporting (Lupton, 1994), some of which has continued to demonise people with, and at risk of, the infection (Persson and Newman, 2008). Other newly infectious diseases outbreaks have sponsored pronounced news media activity, for example, Ebola (Ungar, 1998), and swine flu (Hilton and Hunt, 2011). News media are also said to influence the decision-making of governments and major health organisations have press offices to shape how their work is represented (Briggs and Hallin, 2016). General publics are aware of media activity on these emerging health threats. Qualitative research on the 2009 swine flu pandemic shows that participants nominated news media as an early source of information and advice (Hilton and Smith, 2010; Davis et al., 2014). 
In this paper, then, we reflect on the role played by news media in the encoding and circulation of AMR narratives. Through close analysis of television, printed and online news in Australia we investigate the manner in which AMR news stories are established for public consumption and what might be some benefits and drawbacks of this media activity. This analysis is important for policy and communications strategy in Australia, but also more generally for enlarging the scope and depth of social analysis of AMR mediality. In what follows, we outline our assumptions about news media and health and discuss AMR news and its resonance with more general concerns of health in socio-cultural context.

\section{Background}

\section{News media and health}

News media do not simply confer on publics ways of thinking and acting. Communications theory shows that media content is subject to social processes of encoding and decoding such that the meaning and effects of any particular message are open to transformation and reinterpretation (Hall, 1980). As Paul Ricoeur famously noted (1981), narratives gain their social potency in their reading. Authors cannot guarantee that words and images will be interpreted in the ways they intended, a feature of media that has particular resonance in the era of Twitter, for example. Convening audiences in ways that encourage deliberation on matters of health and illness may not create audience unity and can give rise to appropriations and resistances that help to form counterpublics (Warner, 2002). This interpretive volatility is partly what makes media, including news, compelling sites for cultural production and political debate.

Moreover, news content is not always pivotal. In relation to the 2009 influenza pandemic, for example, members of the general public in Australia (Davis et al., 2014; Holland and Blood, 2012) and the UK (Hilton and Smith, 2010), reported that they found news media to have hyped 
the pandemic. In contrast, content analyses of news media in Australia (Holland et al., 2012) and the UK (Hilton and Hunt, 2011) showed that reporting was generally factual and not inflammatory. This discrepancy can be taken to reflect audience responses, not to the content of the news stories, but to their observation of the scale of reporting (Davis and Lohm, 2020).

News media on AMR are also subject to commercial imperatives and technological transformations that have implications for what stories they publish and how they construct them. Commercial news media depend for their survival on attracting and securing audiences (Webster, 2017). Public broadcasters, such as the Australian Broadcasting Corporation, have to keep pace with these changes and ensure audience share to justify their use of public funds. These dynamics are subject to particular intensification in the digital media era. Journalists can now receive data on page view frequency and duration (Welbers et al., 2015), information that intensifies the datafication of newsworthiness in ways that can influence decisions about content (Webster, 2017). Furthermore, television news reporters rely on compelling vision to produce stories. Knowledge of how these dynamics influence AMR news production are important for assessment of the role news media may play in public health strategy.

It follows, too, that attention needs to be given to the multimodal properties of news media. Television news items construct linear narratives through the sequence of images across the news item (Squire et al., 2014). Digital news sources combine text, images, video, colour, layout and hyperlinks to create pronounced polysemia (Kress, 2010) and do not necessarily encode linear progression in an orthodox way. This multimodal and transmedia diversity needs to be addressed in analysis of AMR news to contend with the options audiences now have before them. It is necessary to analyse news sources together to understand contemporary practices of AMR storytelling and their implications for audiences. 


\section{AMR in the news}

News media on AMR, then, can be sources of information and play a role in the production and circulation of socio-cultural responses, but not without considerable interpretive and technological complexity and ramification. Investigating the content of printed news, researchers have found that information about AMR is presented inconsistently and with omissions. German newspapers present AMR with little reference to scientifically-derived knowledge (Boklage and Lehmkuhl, 2018). Swedish newspaper articles and webpages on AMR generally omitted scientific explanation of the causes of AMR (Bohlin and Host, 2015) as did online newspapers from US, Canada, UK, India and Australia (Singh et al., 2016). UK newspapers have been found to encourage readers to attribute blame for AMR outside themselves (Donyai et al., 2013). Saliba et al. (2016) compared UK and Indian press on the discovery of New Dehli metallo- $\beta$-lactamase and found that news articles in India focussed on the controversial naming of the microbe. DeSilva et al. (2004) found that only a minority of newspaper articles from the US and Canada provided advice on how to reduce risk of AMR. Australian news media have been found to report on AMR with accuracy but to also use metaphors that externalised personal responsibility (Bouchoucha et al., 2018). These findings indicate that news media texts may not currently be useful sources of information about AMR, though it should be noted that journalists may not see that public education is a news media role (Briggs and Hallin, 2016).

News media stories on AMR have also been found to mobilise socio-cultural responses to threat that may inhibit effective action. News media fascination with methicillin-resistant staphylococcus aureus (MRSA) peaked in the mid 2000s in the UK (Washer and Joffe, 2006; Crawford et al., 2008) and in Australia (source: Factiva). Washer and Joffe (2006) used social representations theory (SRT) to explain how the meanings of MRSA gained their social potency. SRT posits that news narratives signpost meanings to engage audiences, much like a children's book might combine words and images to establish a storyline and its meaningfulness for a new 
reader. Washer and Joffe argue that the 'dirty hospital' metaphor anchored MRSA to dirt, a powerful sign of threat to bodily and social boundaries (Douglas, 1966). In addition, UK media have been found to regularly confer human intelligence on MRSA and draw on battle narrative, with MRSA as invader and patients as victims (Crawford et al., 2008). This use of military metaphor is well known (Sontag, 1988), and echoes the folk tale structure - heroes, villains, victims - that is common in media on health (Seale, 2002). Focussing on AMR in UK newspapers, Collins et al. (2017) found that news texts tended to erase individual responsibility and invested AMR bacteria with human-like agency.

Also examining UK newspaper accounts of MRSA, Brown and Crawford (2009) have argued that the dirty hospital metaphor sits at odds with the scientific modernisation narrative, because it troublingly shows that human organisation has failed to meet its aspirations for the domination of nature. As Brown and Crawford point out, this way of understanding MRSA sits in contrast with Ungar's account of UK and US newspaper stories on Ebola (1998) and avian flu (2008), which he found to be organised into three phases: alert, contagion/mutation, containment. In this structure, the fearsome viruses emerge and audiences are alerted to their existence. The spread of the viruses, their effects and efforts to address them are the topics of subsequent stories. In the containment phase, the eventual control of the infection and its effects are explained for audiences, most particularly through reports of the action of scientists and other experts. This general pattern therefore raises the prospects of a fearful contagion (disruption of the social order) but then reassures audiences (reinstatement of the social order). This pattern of an event followed by its aftermath is axiomatic to narrative and common in restitution narratives concerning recovery from an illness or surgery (Frank, 1995). This overall reassuring pattern of news on pandemics helps to 'immunise' publics from the ontological threat implied by infections and outbreaks (Meek, 2016). AMR has been figured as an antibiotic apocalypse (Nerlich, 2009), discourse that is used by experts to influence governments and promote scientific inquiry. But 
this story-telling approach may lead publics to believe that there is little they can do to address the problem. Similarly, Catherine Will (2020) has shown how opportunities for citizen participation in AMR are decreasing because policy and communications favour simply nudging individuals into action in ways that do not require reflexive agency. These perspectives suggest that news audiences are reassured and made passive, approaches that augur poorly for democratic engagements with threats to life.

AMR news narratives also draw on the more general biopolitics of immunity. In particular, they draw on notions of the interior of the body as a site for action to protect health and as the primary arena for scientific discoveries that can transform the health prospects of individuals and populations. The medical historian Ed Cohen has shown how scientific discoveries of the immunological properties of bodies led to a focus on "milieu interieur" (Cohen, 2009, page 196). This imaginary of the interior body coupled with the protective individualism inherent to immunity created a focus on the management of the processes and effects of the inner workings of the body. It was also a principle that created a new emphasis on the laboratory-based medicine able to reveal the 'milieu interieur', displacing older forms tied to the bedside and the hospital. Scientists through their discoveries became celebrated figures of immunology, as demonstrated by the many Nobel Prizes the science has attracted during the twentieth and twenty-first centuries, including for Burnet mentioned above. Building on Cohen, Nik Brown (2019), has argued that AMR is a key flashpoint for immunitary life, due to the ways in which it represents the failure of a once triumphant biomedical technology, leading to significant challenges for the status of biomedicine in the social order. Failing biotechnology and growing threat to life accentuates notions of the besieged self and the need to bolster personal immunity as a form of protection from a threatening world (Cohen, 2009; Davis and Lohm, 2020). It also leads to a focus on what science may be able to do to arrest the prospect of the continued failure of antibiotics. 
In this paper, then, we address how Australian media have encoded and circulated news of AMR, both as a potential source of information and advice for audiences and as sites for the socio-cultural production of responses to this threat to life. Our research, distinctively, analyses television, printed and digital news sources together and with reference to the multimodal properties of each. As we explain below, we have also chosen to focus on AMR news in 2017, in part because of the complexity of the materials we have collected, but also so that we can examine AMR story-telling through a close-focus lens, offering detail that is washed out of longitudinal content surveys of news texts.

\section{METHODS}

\section{Media sampling}

Our research focussed on news sources chosen to address the multimodal and transmedia diversity of news media on AMR. We selected sources available throughout Australia and from the state of Victoria, which is the second most populous state in Australia and the site for our Australian Research Council-funded research on AMR communications. We did not include radio as audio is challenging to collect and analyse. We selected media sources according to these criteria: television (all national, public and commercial free to air broadcasters); newspapers (highest readership, by Roy Morgan analytics, in Australia and the state of Victoria; mix of national and Victorian metropolitan and regional outlets; mix of broadsheets and tabloids); digital news (the most visited news sites in Australia (by Nielsen Digital Ratings) with searchable and downloadable content).

We used several data-bases to identify relevant items. From mid 2007, Informit TV News has captured recordings of all free to air, news and current affairs broadcasts in Australia from public broadcasters (Australian Broadcasting Corporation (ABC TV) and Special Broadcasting Service (SBS), 
and commercial channels Channels 7,9 and 10). Factiva is an extensive archive of Australian printed news items that allowed us to select newspapers according to readership and regional mix (The Age; The Australian; The Australian Financial Review; Geelong Advertiser, Herald Sun). Digital news presented some challenges. Pay walls restrict access to pages and search engines, and different news sites use different search algorithms, creating what appeared to be unpredictable search results compared to, for example, Google domain searches. Google domain searches ('Advanced Search' using the source URL and search terms and parameters) enabled capture of online items in a consistent manner, but not from domains protected by pay walls. Moreover, Google domain searches perform according to cookies and other parameters particular to different computers. Online materials are also more numerous than television and newspapers and often have embedded multimedia, further complicating materials collection and analysis. To address these challenges, we ranked the top ten online news sites (by page views according to Nielsen Digital Ratings) and used Google domain searches (on a single computer) for each site that permitted access (news.com.au; abc.net.au; au.news.yahoo.com; theage.com.au; heraldsun.com.au) for the period 1 January to 31 December 2017. This sample mixed public and commercial sources and captured sources that have television or printed companion sources (e.g., abc.net.an and $A B C T V$ News, theage.com.an and The Age, heraldsun.com.an and The Herald Sun). We used several search terms (antibiotic*; flesh-eating bacteria; golden staph*; MRSA; superbug*) to identify relevant items for all media. 'Flesh-eating bacteria' helped to identify stories related to necrotising fasciitis and 'golden staph' is a common name for MRSA. Using these terms we found the following numbers of items for corresponding time periods: television n=271 (1 January 2008 to 31 December 2017); printed news n=2265 (1 January 2008 to 31 December 2017), and; online news n=1206 (1 January 2017 to 31 December 2017). All these items were inspected and removed if they were: identical repeats from the same source; stories not about AMR, i.e., the search term appeared only once in text and was tangential to the meaning of the text; items were $<15$ words; obituaries and court reports; TV guides; stories on flesh-eating zombies, cannibalism in film, TV 
and book reviews; cookery; stories of the illnesses (i.e., antibiotics) of celebrities, politicians, sports people; and sick horses. This procedure yielded 157 television items, 577 printed items and 131 digital items.

Television videos were downloaded and transcribed verbatim and printed news items were downloaded as PDFs. All were entered into NVIVO 12 for analysis. Digital news items were entered directly into NVIVO using the NCapture tool, which allows text, image and layout capture. Videos ( $\mathrm{n}=27)$ accompanying digital items were captured separately, downloaded, transcribed verbatim and inputted to NVIVO. As previously discussed, in what follows we focus on all selected television, printed and online materials for 2017. Table 1 shows the final samples for each month in 2017.

Table 1. AMR news items from television, printed and online news, 2017

\begin{tabular}{|c|c|c|c|c|c|c|c|c|c|c|c|c|c|}
\hline & Jan & Feb & Mar & Apr & May & Jun & Jul & Aug & Sep & Oct & Nov & Dec & \\
\hline \multicolumn{14}{|c|}{ TV news } \\
\hline Channel $7(20.9 \%)^{*}$ & 0 & 0 & 0 & 0 & 0 & 0 & 1 & 0 & 1 & 2 & 0 & 0 & 4 \\
\hline Channel $9(19 \%)^{*}$ & 1 & 1 & 1 & 0 & 0 & 0 & 2 & 1 & 0 & 0 & 0 & 0 & 6 \\
\hline$A B C T V(13.4 \%)^{*}$ & 0 & 1 & 1 & 2 & 0 & 0 & 2 & 0 & 1 & 1 & 0 & 0 & 8 \\
\hline Channel $10(10.8 \%)^{*}$ & 0 & 0 & 0 & 2 & 0 & 2 & 1 & 0 & 0 & 0 & 0 & 0 & 5 \\
\hline SBS $(5.9 \%)^{*}$ & 0 & 0 & 0 & 2 & 0 & 2 & 2 & 0 & 0 & 1 & 0 & 0 & 7 \\
\hline & & & & & & & & & & & & & 30 \\
\hline \multicolumn{14}{|c|}{ Printed news } \\
\hline Herald Sun $(857,000)^{* *}$ & 0 & 0 & 1 & 2 & 2 & 2 & 2 & 2 & 1 & 2 & 1 & 0 & 15 \\
\hline The Age $(472,000)^{* *}$ & 1 & 1 & 2 & 2 & 1 & 3 & 3 & 1 & 4 & 5 & 4 & 0 & 27 \\
\hline The Australian $(333,000)^{* *}$ & 3 & 2 & 3 & 1 & 2 & 0 & 3 & 4 & 0 & 2 & 1 & 1 & 22 \\
\hline Aust. Fin. Review $(119,000)^{* *}$ & 0 & 0 & 0 & 1 & 1 & 0 & 0 & 2 & 0 & 1 & 1 & 1 & 7 \\
\hline Geelong Advertiser $(49,000)^{* *}$ & 1 & 0 & 1 & 1 & 1 & 1 & 4 & 0 & 0 & 2 & 1 & 1 & 13 \\
\hline & & & & & & & & & & & & & 84 \\
\hline \multicolumn{14}{|c|}{ On-line news } \\
\hline news.com.au $(5,449,000)^{* * *}$ & 4 & 1 & 0 & 6 & 3 & 2 & 4 & 3 & 2 & 5 & 0 & 1 & 31 \\
\hline abc.net.au $(4,709,000)^{* * *}$ & 2 & 4 & 2 & 2 & 4 & 1 & 6 & 2 & 4 & 1 & 5 & 1 & 34 \\
\hline theage.com.au $(2,665,000)^{* * *}$ & 1 & 4 & 4 & 4 & 0 & 3 & 4 & 2 & 1 & 3 & 5 & 0 & 31 \\
\hline au.news.yahoo.com $(2,607,000) * * *$ & 1 & 1 & 0 & 0 & 0 & 1 & 1 & 0 & 1 & 1 & 4 & 1 & 11 \\
\hline \multirow[t]{2}{*}{ heraldsun.com.au $(2,545,000)^{* * *}$} & 2 & 0 & 1 & 4 & 1 & 2 & 3 & 2 & 3 & 3 & 1 & 2 & 24 \\
\hline & & & & & & & & & & & & & 131 \\
\hline
\end{tabular}

\section{Analysis}

The television and newspaper materials (2008 to 2017) were placed in order of date of publication and every $5^{\text {th }}$ item was selected for thematic, inductive analysis that comprised open 
coding, constant comparison and interpretive memoranda to generate themes. For this inductive analysis, all co-authors coded a subsample of television news items and conferred to agree a coding map to be used for the remaining materials. These codes were derived from the transcriptions and our reading of the social science, medical, policy and communications literature on AMR. This coding map, as in inductive analysis in general, evolved over the course of the analysis. Using this coding map, we then coded all of the television, printed and digital news items from 2017 (see Table 1). This process identified several key themes (discovery, alert, advice, survivor story), which we describe below. We also content coded all materials from 2017 to examine patterns over time. MD and BL content coded all items for: media type; media source; date of publication; word length or duration; name of author or anonymous. Using the four themes identified, we recoded the 2017 materials according to these criteria: discovery reference to journals, reports, data, or scientists; alert - the negative implications of AMR for Australia; advice - address to the reader or audience and how they should act on AMR; survivor stories - first person, second person accounts of affected people. This content re-coding gave a sense of the relative prevalence of the different themes. Note that these category labels are not mutually exclusive; a single news story can have multiple themes contained within it.

\section{FINDINGS}

\section{AMR news interest and diversity}

Figure 1 shows the monthly frequency of television, printed and digital news items and indicates low interest, consistent with previous years in Australia. For example, the annual average count for AMR printed news items (2008 to 2017) was 51, a figure similar to other findings (Bouchoucha et al., 2018). For comparison, in 2014, 516 printed news items from our printed Figure 1. Digital news, printed news and television on AMR in 2017. 


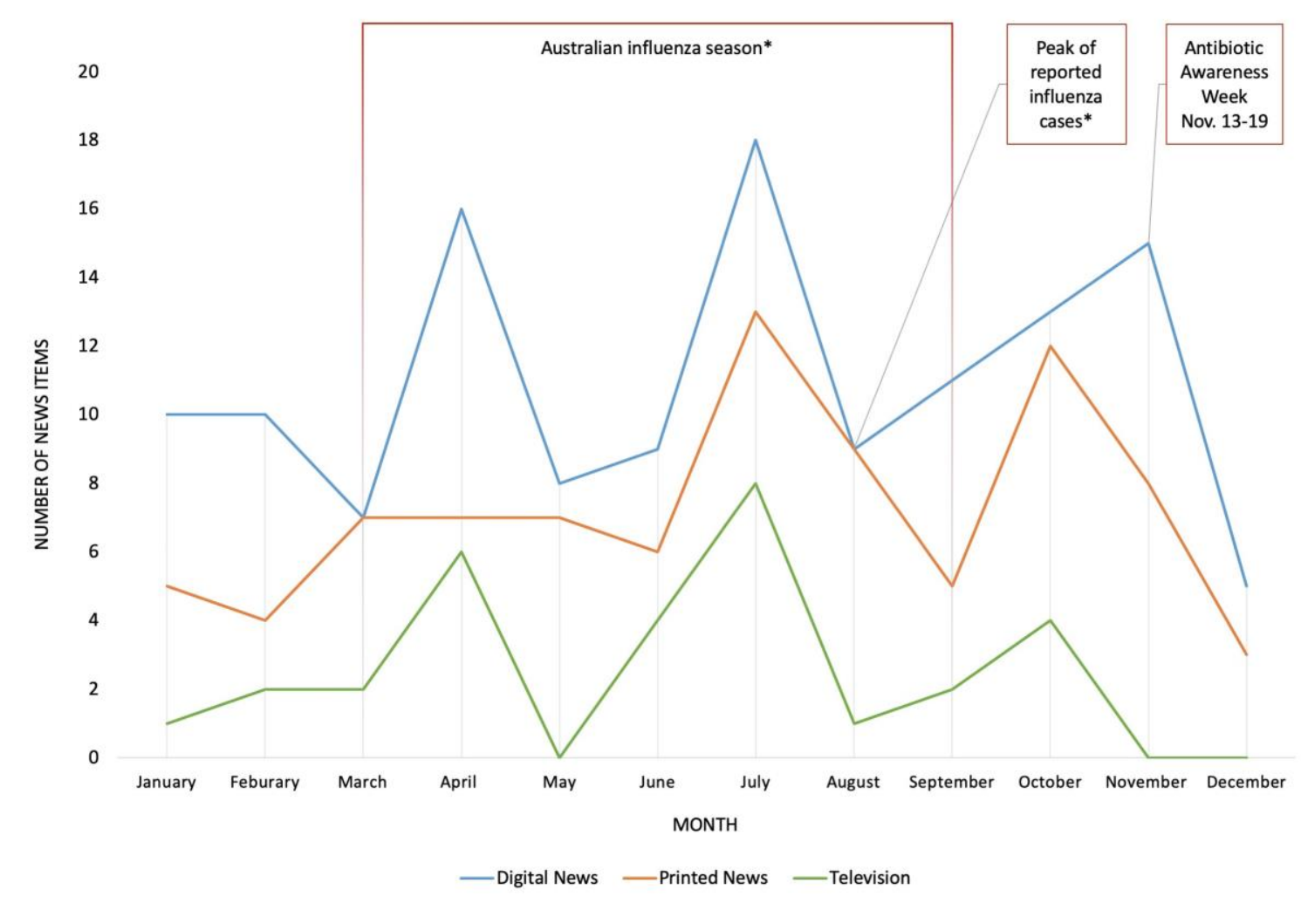

* (Australian Government Department of Health and Ageing, 2018).

news sources addressed the Ebola outbreak in west Africa (source: Factiva). Figure 1 also suggests that the Australian influenza season and annual Antibiotics Awareness Week were not aligned closely with news media activity, though the peak of interest across media in July, may anticipate the typical peak incidence of flu and respiratory illnesses in August and hence the treatment of secondary infections with antibiotics (Department of Health, 2018).

We also found media specific diversity in the topics of AMR news. Close examination of stories published in the peak month of July (see Figure 1) showed that only two stories - a report on the overuse of antibiotics in infants published in the Journal of Paediatrics and Child Health and a report from the WHO on drug-resistant gonorrhea - were carried across all media, but with marked differences. Digital news sources carried the gonorrhea story on seven occasions, while newspapers carried the story twice and television once. In contrast, digital news carried the antibiotics and infants story twice, while television and newspapers carried it on three and four 
occasions, respectively. Other differences for the July AMR news were: news of research on whether or not to complete a course of antibiotics was carried twice on television and once on digital news; television, alone, carried a story on bacteriophage therapy; unlike other media, digital news carried a story on the Human Ken Doll's MRSA infection and a story on whether, given superbugs, it is now advised to 'hand bump' in preference to shaking hands. Previous research has suggested that news media convey partial accounts of AMR knowledge (Boklage and Lehmkuhl, 2018; Bohlin and Host, 2015; Singh et al., 2016). Our findings indicate that AMR news is also subject to considerable source specific diversity.

It is also important to acknowledge the multimodality of the media forms we analysed.

Television news items included long stories from current affairs programmes ( $A B C$ TV's Four Corners, Catalyst, Landline, Behind the News) and magazine shows (Channel Ten's The Project).

Television, as expected, made use of its multimodal capacities, using images, sound and words to convey information and lived experiences. Digital news was also richly multimodal (words, images, videos, layout), but tended to, what we regard to be, open assemblages of these elements where the intentions of the author(s) and meanings conveyed were not always straightforwardly coherent. For example, an item based on a British Medical Journal article drawing attention to inappropriate antibiotic prescribing in the children's animation, Peppa Pig, included an unrelated animation from the show (14 December, news.com.au and beraldsun.com.au). In another example, a news item about a woman amputee included a video from Channel 7 news about a parasite infection of an Australian tourist (au.news.yahoo.com, 25 October). Digital news items like these gave the impression of the piecing together of available materials as opposed to coherent AMR storytelling. Where television news items were conventionally linear, digital news seemed more like a smorgasbord of sources for the audience to choose between for themselves, not all of which addressed AMR, an effect which is said to be characteristic of the digital media turn (Lupton, 2015). This source specific multimodality may help to fragment the AMR storyline. 


\section{AMR narratives across media in 2017}

Alongside the media specific diversity we identified, were the meanings conveyed by the stories.

Table 2 identifies the key AMR themes we identified, along with examples.

\section{Table 2. AMR news themes in 2017}

\begin{tabular}{|c|c|c|}
\hline Narrative & Explanation & Examples \\
\hline Discovery & $\begin{array}{l}\text { Quest for, and discovery of, new } \\
\text { knowledge, most often linked with } \\
\text { science and scientists, as so: } \\
\text { Orthodox science (journal articles, } \\
\text { government reports, new data); } \\
\text { Unusual science (odd discoveries, } \\
\text { e.g., sea turtle bacteria, maggots); } \\
\text { Innovation (new technologies and } \\
\text { industry, e.g., rapid test); Prizes } \\
\text { (awards for scientists, e.g., Eureka } \\
\text { Prize) }\end{array}$ & $\begin{array}{l}\text { One of the great fears of modern medicine is being unable to beat super-bugs with } \\
\text { antibiotics. Now, Australian researchers may have found a way of saving us all from a return } \\
\text { to the 15th century. They've developed what is being called the biggest breakthrough since } \\
\text { penicillin. [15 September, Seven News] (2017) } \\
\text { A landmark report in The Lancet medical journal said more needed to be done to address } \\
\text { inappropriate medicine, which includes deliberate over-servicing by doctors for their own } \\
\text { financial gain. [10 January, The Age] (Medew, 2017) } \\
\text { A study of } 73 \text { green sea turtles has revealed many were carrying drug-resistant } \\
\text { enterobacteriales, a type of bacteria including E. coli, which can lead to serious infections in } \\
\text { humans. [12 June, theage.com.au] (Spooner, 2017) }\end{array}$ \\
\hline Alert & $\begin{array}{l}\text { A variant of discovery, with emphasis } \\
\text { on new knowledge/data as a source } \\
\text { of alarm in the present. Often linked } \\
\text { with research and scientific } \\
\text { milestones but focus on an imperilled } \\
\text { present. Alert storytelling bridges } \\
\text { discovery and advice. }\end{array}$ & $\begin{array}{l}\text { We might be back on the verge of, of the Armageddon we often feared: untreatable, } \\
\text { bacterial infections. [17 June, Ten Eyewitness News] (2017) } \\
\text { Experts fear the death of a woman from a superbug could signal the start of an era where } \\
\text { simple childhood illnesses are invincible to antibiotics, making them a lethal threat. [17 } \\
\text { April, Geelong Advertiser](van den Berg, 2017) } \\
\text { Doctors warn "the world is facing an antibiotic apocalypse" [11 October, news.com.an] } \\
\text { (Schwarz, 2017) }\end{array}$ \\
\hline Advice & $\begin{array}{l}\text { An approach that addresses the } \\
\text { individual media consumer in terms } \\
\text { of their behaviour and/or orientation } \\
\text { to AMR and antibiotics. }\end{array}$ & $\begin{array}{l}\text { But I suggest trust your doctor and if they give good reasons for an antibiotic not being used } \\
\text { then it would be reasonable to accept it. [28 July, Channel Ten, The Project] (2017) } \\
\text { Dr Gillings recommended Australia have better public awareness campaigns on antibiotic } \\
\text { use and ban them in animal farming. He said people needed to finish their courses of the } \\
\text { drugs and hospitals needed to better enforce hygiene practices to stop the spread of } \\
\text { superbugs. [1 March, The Age] (Booker, 2017) } \\
\text { You can help prevent antibiotic resistance by: not requesting antibiotics for colds and flu, } \\
\text { which are caused by viruses. [1 February, theage.com.au] (Arlington, 2017) }\end{array}$ \\
\hline $\begin{array}{l}\text { Survivor } \\
\text { story }\end{array}$ & $\begin{array}{l}\text { Stories of individuals with an AMR } \\
\text { infection, often: personalised; } \\
\text { emotional; depicting severe effects of } \\
\text { untreatable infection; and including } \\
\text { images. }\end{array}$ & $\begin{array}{l}\text { Patient: I could see my tibia out the side of my leg so I knew it was serious. } \\
\text { Narration: On holiday in Zambia she stepped into an uncovered, service hole. The real } \\
\text { danger not in the shattered bone but the antibiotic-resistant infection that came with it. } \\
\text { Patient: I was devastated. I cried and cried. [28 June, SBS Television] (2017) } \\
\text { Rather than go to her doctor or bother her family, the } 79 \text {-year-old decided to take matters } \\
\text { into her own hands. She rifled through her medicine cabinet and took old antibiotics. . "Her } \\
\text { prognosis got worse and it was because she took out-of-date medicine" [16 July, The Sunday } \\
\text { Age](Berry, 2017) } \\
\text { "It just felt like somebody was down there with a saw going to cut my leg off," he said. } \\
\text { "I woke up with throbbing in the leg. I switched the light on to have a look and it was about } \\
\text { the size of a football, my left ankle. [10 March, abc.net.au] (Keane, 2017) }\end{array}$ \\
\hline
\end{tabular}

\section{Discovery}

Scientific discovery was the dominant theme: $69 \%$ of news items were found to exercise

discovery themes through a mixture of orthodox and unusual science, industrial and 
technological innovation, and the accolades given to scientists. AMR was, therefore, a matter of science, framed in terms of the implications of new knowledge for the human project of survival. In this example, the achievements of scientists were pitched against the threat presented by AMR:

A team of researchers led by scientists from the University of $W A$ bas made a significant breakthrough in the fight against super-bugs. They've discovered a protein which masks bacteria from the body's immune system and makes them resistant to antibiotics. These super-bugs kill hundreds of thousands of people each year and that number is rising. [15 February, ABC TV](2017a)

This and other examples of AMR discovery depict what science can reveal about microbial life and therefore its powers to generate new knowledge. These stories echoed the 1940s news media we introduced previously on the use of penicillin to cure common infections and caution with regard to the development of resistance. The news items from 2017 help to reinforce the 'milieu interieur' (Cohen, 2009), of the life sciences and the related dominance of the laboratory and experimental science in the production of knowledge for health. This effect was underlined by AMR stories that only indirectly connected with humans, for example, the story from the theage.com.an on sea turtle bacteria (see Table 2). Scientific curiosities like these helped to show in another way the discovery powers of science.

Discovery narrative exhibited a reliance on the reported/videoed speech of scientific experts and authorities, a recognised technique observed in reporting on avian influenza (Ungar, 2008), Ebola (Ungar, 1998), and swine flu (Davis, 2017). Television featured still and moving images of laboratories, scientists in white coats, hospitals and headshots of researchers and clinicians. The online videos were a mixture of video recorded experts providing information, advice and infographics. These visualisations of expertise and authority lent force to the notion that AMR is 
a focus for those able to gain purchase on it through scientific methods, their knowledge, and professional roles.

The dominance of these discovery stories indicated that news media are not preoccupied with AMR as an antibiotic apocalypse (Nerlich, 2009), public health crisis (UK Review on Antimicrobial Resistance, 2016), or as the unfulfilled promise of science (Brown and Crawford, 2009). These metaphors are present, but they are submerged into the discovery narrative and the other narratives we have identified. The preference for discovery stories underlines AMR's distinctive biopolitical history. As noted, Australian and UK media interest in MRSA - the most well-known superbug - peaked in the mid 2000s and was associated with dissent over the management of hygiene in hospitals (Washer and Joffe, 2006). The more recent turn to science and its discoveries may indicate that the newsworthiness of the AMR crisis has passed and that stories now exercise reassurance. In this mode of story-telling the focus is on the hero scientist and their ability to preserve audiences from the threats entailed in superbugs. These stories perform, then, socio-cultural 'immunisation' of audiences form the ontological threat of invading microbes.

\section{Alert}

As Table 2 indicates, the alert theme links discovery with advice. It is an approach that depends on discovery but looks to the public interest in terms of alarm, warning or caution. This theme, however, was present in $22 \%$ of news items, strengthening the point we have made that that AMR news is largely in the reassurance/immunisation phase of reporting. Significantly, too, alert and discovery narratives occur contemporaneously and therefore unlike the news on pandemics when alert stories prefigure discovery and its associated meanings of reassurance (Ungar, 1998). This temporal blending of alert and discovery underlines the perspective that AMR news has passed into a period of reassurance. Moreover, despite this more obvious orientation to alerting 
publics of the ramifications and effects of AMR, the sense of apocalypse or crisis was tempered (Nerlich, 2009). For example, a video of an interview with ABC TV was embedded on several occasions in items from theage.com.an:

[Cheryl Jones, University of Melbourne, to camera - Sydney in background]: In January of this year the Centre for Disease Control in the United States reported the case of a woman who had died from an untreatable infection. That infection she'd acquired while she was travelling India, where she'd broken her leg and had surgery. When she returned to the United States, the infection spread throughout the body. What alarmed us was what they isolated from that infection, which was a bacteria called klebsiella pneumoniae, that was resistant to all of our antibiotics. (ABC TV, 2017b) (embedded video, 2.42 seconds, from ABC TV News: 16 April, 9 July, 28 July, theage.com.au)

In this example, the death of the woman with an untreatable infection is new knowledge (discovery) but also cause for some alarm. The overall effect of this and similar examples was to reassure audiences that scientific experts are active and seeking out means of addressing AMR. Alert narrative, therefore, also works to secure the hegemony of scientific rationality. The example above also underlines AMR multimodality, since this $A B C T V$ video was used on three occasions on theage.com.au.

\section{Advice}

We found that $18 \%$ of news items in 2017 published advice on how audiences could address AMR, echoing other research (DeSilva et al., 2004). When it was given, advice was not always fulsome, for example:

And experts say it's not just up to bealth authorities and physicians to reduce antibiotic use. They say it's up to all of us as patient to ask are antibiotics really needed. [17 April, ABC TV] (2017b) 
We did observe, however, that online news media in some instances publish detailed 'explainers'. An abc.net.au article entitled 'Australian scientists make breakthrough in fight against superbugs', (15

February) included information about antibiotics in a highlighted box and a permalink to another page 'Antibiotic resistance explained', which provided a lengthy description of AMR, including information on: how antibiotics work, gut biome, prescription compliance and overuse, and the importance of antibiotics for major surgery. Other news pages embedded videos, including informative animations of AMR and experts relating facts and advice. This extract comes from a video that was repeated eight times across two sources:

[narrator's headshot] Not only that, but strains of bacteria will become resistant to the new antibiotics within 2 to 3 years anyway. Instead, we should be taking antibiotics only when we need then, and using them properly [image of hand washing] ... when we do, by taking the entire course. As always, prevention is key, so doing things like having good hand hygiene, [image of needle drips] keeping your vaccination up to date and [image of woman running toward sunset] staying in good shape, will keep the infections away in the first place. (embedded video, 1.30 seconds: 3 January, 17 April, 10 May, 7 July, 11 October, news.com.au; 17 January (twice), 26 September, beraldsun.com.au) (King, 2017)

Unlike other advice, in this example audiences were encouraged to avoid infection, vaccinate, stay healthy and, by implication, to boost their immunity. The provision of advice about AMR therefore connected with a more general public culture of immunity and its emphasis on selfprotection (Cohen, 2009; Brown, 2019; Davis and Lohm, 2020). In light of the predominance of scientific discovery narrative, news texts support a general schema that scientific experts will provide the means to control AMR while publics are asked to comply with medical advice and, on occasion, care for their immunity. Will (2020) made the point that AMR messages tended to treat audiences as lacking knowledge and agency. A similar pattern is seen in news texts because they also tend to circumscribe action on the part of audiences. Advice like this may lead them to 
believe that there is not much they can do other that focus on their personal immunity (Davis and Lohm, 2020).

\section{Survivor story}

This theme was identified in $17 \%$ of news items from 2017. These stories were evidence of the impact of AMR - the victims of superbugs - and therefore grounded the overall AMR news effort in human interest. Table 2 referred to notable examples of the survivor story type that named the affected person, explained how they were thought to have been infected and then what had happened to them. These were the most obvious examples of illness narratives (Frank, 1995), since they documented the impact and aftermath of untreatable or difficult to treat infections. These survivor stories have a dual quality. They demonstrate that AMR can be debilitating and therefore undermine the reassuring discovery narrative that dominates the news of AMR. But survivor stories provide audiences with glimpses of the ordeal of AMR's victims and how they were able to secure life after infection. These narratives only partly assert restoration of health as it was (Frank, 1995), but they do affirm that life is possible after AMR. Survivor narratives therefore disrupt and then re-instate the reassurance to be found in most AMR stories.

Survivor narrative heteroglossia was indicated also through the use of images. Survivor stories often reported on surgery and amputations and included, on occasion, images of infected wounds. These gruesome images reinforced the personal testimonial qualities of these reports and provided visual evidence for the reader. But, these images were recycled from other media. For example, 'Man with new tattoo goes swimming, dies from flesh eating bacteria' [1 June, au.news.au.news.yahoo.com] (anon, 2017a), was based on a case report from the British Medical Journal of a man who had swum in the Gulf of Mexico and reproduced the images of the man's infected legs from the article; and; 'Mum has hands, feet amputated after contracting flesh-eating disease 
giving birth' [25 October, au.news.yahoo.com] (anon, 2017b), which reported on news of a Canadian woman who had given birth six months before. The relevance of these articles for Australian audiences in 2017 was unclear. The affected woman was quoted as having spoken of her experience as akin to "a horror movie", indicating perhaps that a key criterion of newsworthiness was the ability of the story to mobilise the horror genre. These images have the potential to disrupt the reassurance provided by discovery narrative and may be aversive for some readers. One online item, 'Flesh-eating necrotising fasciitis: What causes it and how is it treated?' [17 November, abc.net.au] (Cheng, 2017), included a 'graphic warning' for the audience. In this particular example, the audience was offered some protection from the potentially upsetting quality of some images, revealing a commitment to reassurance and ultimately a form of immunisation from the horror of AMR. Survivor narrative and its sometimes gruesome spectacle, then, is the exception that proves the overall commitment of the news to the welfare and capture of its audiences.

\section{CONCLUSION}

Focussing on printed, television and digital news in 2017 set into the context of news reporting since 2008, we provided an analysis of the patterns and narratives in AMR news. This approach was necessary to achieve depth and nuance in the analysis of transmedia news sources, an approach not available in content analysis of large data sets. We accept, therefore, that our findings offer a circumscribed basis for inferences about news media in other nations and time periods, though the analysis we offer does uncover important multimedia dynamics that may apply in different ways in other contexts.

We observed that AMR news media items from 2008 to 2017 were regular but low frequency, in line with data reported from Australia (Bouchoucha et al., 2018). This apparent flat-lining in AMR news provided little sense of the impending crisis found in public policy statements (UK 
Review on Antimicrobial Resistance, 2016) and is less than the attention given to MRSA in the mid 2000s in the UK (Crawford et al., 2008; Washer and Joffe, 2006) and Australia (source: Factiva). We also highlighted several dynamics of news media production that contribute to the fragmentation of the overall AMR story. As is well known (Webster, 2017), different types of media (i.e., digital news, printed news, television) attract different audiences. Our analysis added to this picture by showing that digital media, in particular, are marked by accentuated multimodality, that is, words, images, videos, colours and hyperlinks combined in ways that were not necessarily unified. In addition, the economic logic of audience capture may encourage some muddying of the AMR storyline, as the Peppa Pig and horror images examples illustrated. Publics have been found to have little appreciation of their potential role in reducing the drivers of AMR (McCullough et al., 2015; Gualano et al., 2015), a picture that parallels the ways in which AMR is depicted in news media.

Our analysis shows that Australian news stories mainly depict AMR as an example of a general narrative of scientific discovery. In order of decreasing prevalence, discovery narratives were the most often featured (69\%), followed by alert (22\%), advice (18\%), and survivor (17\%). Anxieties possibly evoked by alert were more than balanced with the reassurance available in the amply storied quest for scientific discovery. Notions of medicine's failed promise, public health crisis and the antibiotic apocalypse were tempered by the much more prominent discovery narrative. The advice for publics that did exist was hydraulic: fewer antibiotics, more hygiene, boosted immunity. Survivor narrative was both potentially upsetting for audiences and ultimately reinstated the reassuring message that life persisted after superbug infections. The primary effect of the news, then, was to help to extend the socio-cultural dominance of scientific approaches to AMR (Brown, 2019; Cohen, 2009). These stories benefit the social standing of science and scientists, but a drawback is that scientific AMR narratives perpetuate a world view that limits the agency of audiences. AMR news is peopled with marauding superbugs, hero scientists and 
unlucky victims. Absent are the individual and collective actions nominated in policy frameworks to be vital for the eventual effective management of AMR (UK Review on Antimicrobial Resistance, 2016). As Will (2020), has pointed out in relation to AMR education in the UK, the scope for deliberative approaches to AMR appears to be closing off due to the ways in which publics are characterised as ignorant in policy and communications. Australian news media appear to help consolidate this situation. Unlike pandemics and other newly emerging public health crises (Davis and Lohm, 2020), news media may not be a primary source of useful information for the general public and may also help to further their understanding that there is little for individuals to do in the efforts to address AMR.

Florey, among others, warned of microbial resistance at the dawning of the penicillin age in the 1940s, a period when mass media was also poised to reach its zenith through widespread access to television. These cautionary tales continue to reverberate in the era of digital news media complexity and audience fragmentation, but not as strongly as the valorisation of science and its reassuring quest for discovery. Accordingly, AMR's news audiences are hailed in ways that limit what they can know and do. Finding other ways of telling the AMR story will be vital if the role of news media is to be increased for the global effort to mitigate this challenging threat to life.

\section{Acknowledgements}

This research was supported by an Australian Research Council Discovery Project grant (DP170100937).

\section{References}

ABC TV. (2017a) Superbug battle: Breakthough: A team of researchers led by scientists from the University of Western Australia has made a significant breakthrough in the fight against super bugs. [online]. ABC News WA (ABC1 Perth); Time: 19:00; Broadcast Date: 
Wednesday, 15th February 2017; Duration: 1 min., 43 sec. Availability: < $\underline{\text { https://search- }}$ informit-com-

au.ezproxy.lib.monash.edu.au/documentSummary;dn=TSM201702150227;res=TVNEW $\underline{\mathrm{S}}>$.

ABC TV. (2017b) Superbug: Warning: Australian health experts have issued a dire warning about what might happen if uncontrolled antibiotic use continues. [online]. ABC News NSW (ABC1 Sydney); Time: 19:00; Broadcast Date: Monday, 17th April 2017; Duration: 2 min., 12 sec. Availability: < https://search-informit-comau.ezproxy.lib.monash.edu.au/documentSummary;dn=TSM201704170077;res=TVNEW $\underline{\mathrm{S}}>$.

anon. (2017a) Man with new tattoo goes swimming, dies from flesh eating bacteria, https://au.news.yahoo.com/man-with-new-tattoo-goes-swimming-dies-from-flesheating-bacteria-35721388.html, accessed 1 May 2018. au.news.yahoo.com. Australia: Yahoo. anon. (2017b) Mum has hands, feet amputated after contracting flesh-eating disease giving birth, https://au.news.yahoo.com/mum-has-hands-feet-amputated-after-flesh-eating-diseasecanada-37602083.html, accessed 1 May 2018. au.news.yahoo.com. Australia: Yahoo.

Arlington K. (2017) Superbug risk: high levels of antibiotic resistance genes found in estuaries. theage.com. Melbourne: Fairfax.

Australian Government Department of Health and Ageing. (2018) Australian Influenza Surveillance Report, No. 11, 2018, 8 to 21 October 2018. health.gov.au. Availability: $<\underline{\text { http://www.health.gov.au/internet/main/publishing.nsf/Content/cda-surveil-ozflu- }}$ flucurr.htm/\$File/flu-11-2018.pdf>, accessed 18 November 2018. Berry S. (2017) Using expired medicine can become a deadly cocktail The Sunday Age. Melbourne: Fairfax.

Bie B, Tang L and Treise D. (2016) Be aware of superbugs: Newspaper coverage of NDM-1 in India, UK, and the USA. Asian Journal of Communication 26: 58-75. 
Bohlin G and Host G. (2015) Evolutionary Explanations for Antibiotic Resistance in Daily Press, Online Websites and Biology Textbooks in Sweden. International Journal of Science Education 5: 319-338.

Boklage E and Lehmkuhl M. (2018) Coverage of Antimicrobial Resistance in the German Press: 1993-2013. Health Communication, DOI: 10.1080/10410236.2018.1446250.

Booker C. (2017) The 12 deadliest superbugs: WHO The Age. Melbourne: Fairfax.

Bouchoucha S, Whatman E and Johnstone M. (2018) Media representation of the antimicrobial resistance (AMR) crisis: An Australian perspective. Infection, Disease and Health https://doi.org/10.1016/j.idh.2018.09.084.

Brennan N. (1947) Blood for the blood bank. The Advocate. Melbourne, Australia.

Briggs C and Hallin D. (2016) Making health public: How new coverage is remaking media, medicine, and contemporary life, London: Routledge.

Brown B and Crawford P. (2009) 'Post antibiotic apocalypse': discourses of mutation in narratives of MRSA. Soc Health \& Illness 31: 508-524.

Brown N. (2019) Immunitary life: A biopolitics of immunity, London: Palgrave.

Burnet F. (1941) The good earth: The world of science. The Age. Melbourne.

Cheng A. (2017) Flesh-eating necrotising fasciitis: What causes it and how is it treated?, https://www.abc.net.au/news/2017-11-17/necrotising-fasciitis-flesh-eating-bacteriacauses-and-treatment/9162062, accessed 1 May 2018. abc.net.au. Australia: Australian Broadcasting Corporation.

Cohen E. (2009) A body worth defending: Immunity, biopolitics and the apotheosis of the modern body, Durham and London: Duke University Press.

Collins L, Jaspal R and Nerlich B. (2017) Who or what has agency in the discussion of antimicrobial resistance in UK news media (2010-2015)? A transitivityanalysis. Health: bttps:// doi.org/10.1177/11363459317715777. 
Crawford P, Brown B, Nerlich B, et al. (2008) The 'moral careers' of microbes and the rise of the matrons: An analysis of UK national press coverage of methicillin-resistant Staphylococcus aureus (MRSA) 1995-2006. Health, Risk \& Society 10: 331-347.

Davis M. (2017) “Is it going to be real?” Narrative and media on a pandemic. Forum Qualitative Sozialforschung / Forum: Qualitative Social Research 18.

Davis M, Flowers P, Lohm D, et al. (2014) "We became sceptics": fear and media hype in general public narrative on the advent of pandemic influenza. Sociological Inquiry 84: 499518.

Davis M and Lohm D. (2020) Pandemics, Publics and Narrative, New York: Oxford University Press.

DeSilva M, Musakavitch M and Roche J. (2004) Print media coverage of antibiotic resistance. Science Communication 26: 31-43.

Donyai P, Okafor S, Virgo R, et al. (2013) Messages about Antibiotic Resistance in Different Newspaper Genres. Pharmacy 1: 181-192.

Douglas M. (1966) Purity and danger: an analysis of concepts of pollution and taboo, London: Routledge. Frank A. (1995) The wounded storyteller: Body, illness and ethics, Chicago: The University of Chicago Press.

Gualano M, Gili R, Scaioli G, et al. (2015) General population's knowledge and attitudes about antibiotics: a systematic review and meta-analysis. Pharmacoepidemiology and Drug Safety 24: $2-10$.

Hall S. (1980) Encoding/decoding. In: Hall S, Hobson D, Love A, et al. (eds) Culture, Media, Language. London: Huticinson, 128-138.

Hilton S and Hunt K. (2011) UK newspapers' representation of the the 2009-10 outbreak of swine flu: one health scare not over-hyped by the media? Journal of Epidemiology and Community Health 65: 941-946. 
Hilton S and Smith E. (2010) Public views of the UK media and government reaction to the 2009 swine flu pandemic. BMC Public Health 10: 697.

Holland K and Blood W. (2012) Public responses and reflexivity during the Swine flu pandemic in Australia. Journalism Studies iFirst: DOI:10.1080/1461670X.2012.744552.

Holland K, Blood W, Imison M, et al. (2012) Risk, expert uncertainty, and Australian news media: public and private faces of expert opinion during the 2009 swine flu pandemic. Journal of Risk Research 15: 657-671.

Keane D. (2017) Flesh-eating bacteria strips skin off leg of River Murray boatie, https://www.abc.net.au/news/2017-03-10/flesh-eating-bacteria-strips-leg-of-rivermurray-boatie/8343008, accessed 1 May 2018. anc.net.au. Australia: Australian Broadcasting Corporation.

King R. (2017) How antibiotics are leading to disaster, My body + soul,https://www.news.com.au/lifestyle/health/health-problems/doctors-warn-theworld-is-facing-an-antibiotic-apocalypse/newsstory/4b78a4b445d6f05896e443082895045f, news.com.au, Australia: News Corp Australia, accessed 1 May 2018

Kress G. (2010) Multimodality: A social semiotic apporach to contemporary communication, London: Routledge.

Lupton D. (1994) Moral Threats and Dangerous Desires: AIDS in the News Media, London: Taylor \& Francis.

Lupton D. (2015) Health promotion in the digital era: a critical commentary. Health Promotion International 30: 174-183.

McCullough A, Parekh S, Rathbone J, et al. (2015) A systematic review of the public's knowledge and beliefs about antibiotic resistance. J Antimicrob Chemo, doi:10.1093/jac/dkv310.

Medew J. (2017) Many patients given medicine they don't need The Age. Melbourne: Fairfax. Meek A. (2016) Biopolilitcal Media: Catastrophe, Immunity and Bare Life, New York: Routledge. 
Nerlich B. (2009) "The post-antibiotic apocalypse" and the "war on superbugs": catastrophe discourse in microbiology, its rhetorical form and political function. Public Understanding of Science 18: 574-590.

Persson A and Newman C. (2008) Making monsters: heterosexuality, crime and race in recent Western media coverage of HIV. Sociology of Health \& Illness 30: 632-646.

Ricoeur P. (1981) Hermeneutics and the human sciences: essays on language, action and interpretation, Cambridge: Cambridge University Press.

Saliba V, Washer P, Pett P, et al. (2016) A comparative analysis of how the media in the United Kingdom and India represented the emergence of NDM-1. Journal of Public Health Policy 37: 1-19.

SBS Television. (2017) Doctors warn drug resistant superbugs are on the rise, with patients showing antibiotic-resistant infections presenting every week. [online]. World News Australia (SBS TELEVISION); Time: 18:30; Broadcast Date: Wednesday, 28th June 2017; Duration: 2 min., 28 sec. Availability: < https://search-informit-comau.ezproxy.lib.monash.edu.au/documentSummary;dn=TSM201706280018;res=TVNEW $\underline{\mathrm{S}}>$.

Schwarz K. (2017) Doctors warn "the world is facing an antibiotic apocalypse", https://www.news.com.au/lifestyle/health/health-problems/doctors-warn-the-world-isfacing-an-antibiotic-apocalypse/news-story/4b78a4b445d6f05896e443082895045f, accessed 1 May 2018. news.com.au. Australia: News Limited.

Seale C. (2002) Media and Health, London: Sage.

Seven News. (2017) Superbug: Soluition: One of the great fears of modern medicine is being unable to beat superbugs with antibiotics. [online]. Seven News (SEVEN NETWORK); Time: 18:00; Broadcast Date: Friday, 15th September 2017; Duration: 1 min., 49 sec. Availability: < $\underline{\text { https://search-informit-com- }}$ 
au.ezproxy.lib.monash.edu.au/documentSummary; $\mathrm{dn}=\mathrm{TSM} 201709150102 ; \mathrm{res}=\mathrm{TVNEW}$ $\underline{S}>$.

Singh N, Sit M, Chung D, et al. (2016) How Often Are Antibiotic-Resistant Bacteria Said to "Evolve" in the News? PLOS One 11: e0150396.

Sontag S. (1988) AIDS and its metaphors, London: Penguin.

Spooner R. (2017) Drug-resistant superbugs hitch a ride on Great Barrier Reef turtles, https://www.theage.com.au/healthcare/drugresistant-superbugs-hitch-a-ride-on-greatbarrier-reef-turtles-20170612-gwph6k.html, accessed 1 May 2018. theage.com. Melbourne: Fairfax.

Squire C, Davis M, Esin C, et al. (2014) What is narrative research?, London: Bloomsbury Academic.

Staff Correspondent. (1944) Penicillin in Australia. Sydney Morning Herald, page 2, 13 May. Sydney. Ten Eyewitness News. (2017) Thousands of GPs are being warned by the country's top doctor to stop prescribing anti-biotics this winter, or face dire consequences. [online]. Ten Eyewitness News (TEN NETWORK); Time: 17:00; Broadcast Date: Saturday, 17th June 2017; Duration: 1 min., 52 sec. Availability: < $\underline{\text { https://search-informit-com- }}$ au.ezproxy.lib.monash.edu.au/documentSummary;dn=TSM201706170159;res=TVNEW $\underline{\mathrm{S}}>$.

The Project. (2017) The Project: More dual citizenship dramas in Canberra, but could the latest one bring down the Government? [online]. The Project (TEN NETWORK); Time: 18:30; Broadcast Date: Friday, 28th July 2017; Duration: 43 min., 30 sec. Availability: $<\underline{\text { https://search-informit-com- }}$ au.ezproxy.lib.monash.edu.au/documentSummary;dn=TSM201707280001;res=TVNEW $\underline{\mathrm{S}}>$.

UK Review on Antimicrobial Resistance. (2016) Tackling drug-resistant infections globally: Final report and recommendations. London: Wellcome Trust and HM Government. 
Ungar S. (1998) Hot crises and media reassurance: A comparison of emerging disease and Ebola Zaire. The British Journal of Sociology 49: 36-56.

Ungar S. (2008) Global Bird Flu Communication: Hot Crisis and Media Reassurance. Science Communication 29: 472-497.

van den Berg L. (2017) Superbug fears on rise Geelong Advertiser. Geelong: New Limited.

Warner M. (2002) Publics and counterpublics, Cambride, Mass: Zone Books.

Washer P and Joffe H. (2006) The "hospital superbug": Social representations of MRSA. Social Science \& Medicine 63: 2141-2152.

Webster J. (2017) Three myths of digital media. Convergance: The International Journal of Research into New Media Technologies 23: 352-361.

Welbers K, van atteveldt W, Kleinijenhuis J, et al. (2015) News selection criteria in the digital age: Professional norms versus online audience metrics Journalism 17: 1037-1053.

Will C. (2020) The problem and productivity of ignorance: Public health campaigns on antibiotic stewardship. The Sociological Review 68: 55-76. 